\title{
Akuntabilitas Masjid Berdasarkan Isak 35 di Wilayah Kecamatan Kedungbanteng, Kabupaten Banyumas
}

\author{
Sully Kemala Octisari*, Tjahjani Murdijaningsih, Haina Idam Suworo \\ Fakultas Ekonomika dan Bisnis, Universitas Wijayakusuma Purwokerto \\ *Correspondence email: kemalaoct@gmail.com
}

\begin{abstract}
Abstrak. Tujuan penelitian ini adalah untuk mengetahui akuntabilitas dan kesesuaian pelaporan keuangan lembaga masjid di wilayah kecamatan Kedungbanteng dengan ISAK 35. Penelitian ini menggunakan 14 sampel masjid yang berada di wilayah kecamatan Kedungbanteng. Metode yang digunakan dalam penelitian ini yaitu metode kualitatif deskriptif. Hasil penelitian ini menunjukkan bahwa takmir (pengurus) masjid di wilayah kecamatan Kedungbanteng telah mengelola keuangan masjid secara akuntabel sesuai dengan kriteria yang telah ditentukan. Pencatatan dilakukan dengan baik walaupun masih sederhana. Mengenai Interpretasi Standar Akuntansi Keuangan (ISAK) 35 pengurus masjid belum melakukan pencatatan berdasarkan standar yang telah dikeluarkan oleh Ikatan Akuntan Indonesia (IAI) tersebut. Belum diterapkannya standar tersebut dikarenakan standar tersebut diakui belum pernah terdengar dan diperkenalkan pada pengurus Masjid.
\end{abstract}

Kata kunci: Akuntabilitas; Keuangan Masjid; ISAK 35

\begin{abstract}
The purpose of this study was to determine the accountability and suitability of the financial reporting of mosques institutions in the Kedungbanteng sub-district with ISAK 35. This study used 14 samples of mosques in the Kedungbanteng subdistrict. The method used in this research is descriptive qualitative method. The results of this study indicate that the Takmir (management) of the mosque in the Keungbanteng sub-district has managed the mosque's finances accountably according to predermined criteria. Record keeping is done well even though it is still simple. Regarding the Interpretation of Financial Accounting Standards (ISAK) 35 mosque administrators have not kept records based on the standards issued by the Indonesian Institute of Accountants (IAI). The standard has not been applied because it is admittedly unheard of and introduced to mosque administrators.
\end{abstract}

Keywords: Accountability; Mosque Finance; ISAK 35

\section{PENDAHULUAN}

Berdasarkan tujuannya, organisasi dapat dibedakan menjadi dua yaitu organisasi yang bertujuan mencari keuntungan "profit oriented" dan organisasi yang tidak bertujuan mencari keuntungan "non profit oriented". Organisasi nirlaba adalah organisasi yang memiliki sasaran pokok untuk suatu tujuan yang tidak komersil, tanpa ada maksud untuk mencari laba, Pontoh (2013). Karakteristik organisasi nonlaba berbeda dengan organisasi yang berorientasi mencari keuntungan (laba). Perbedaan yang mendasar yaitu terletak pada perolehan sumber daya yang dibutuhkan untuk melakukan berbagai aktivitas operasinya. Layaknya suatu perusahaan, tranparansi dan akuntanbilitas sangat diperlukan dalam organisasi nirlaba. Untuk mempertanggung jawabkan kinerja oganisasi, diharapkan transparansi dan akuntabilitas diterapkan agar para donatur mengetahui sumber daya yang diberikan, digunakan dengan baik.

Masjid merupakan salah satu contoh lembaga organisasi nirlaba di bidang keagamaan. Berbagai aktivitas yang ada di masjid, tentu saja masjid mendapatkan sumber dana yang dapat berasal dari donatur, infaq, kotak amal atau lainnya. Menurut Andarsari (2016), penyajian laporan keuangan pada masjid biasanya hanya dibuat penerimaan dan pengeluaran kas tanpa memperlihatkan jumlah aset apa saja yang dipunyai oleh masjid, sehingga informasi yang diberikan kepada para pemakai laporan keuangan yaitu donatur masjid tidak sesuai apa yang terlihat karena kelemahan dalam sistem pencatatan laporan keuangannya. Maka penerapan sistem keuangan yang baik akan memberikan jawaban yang tepat atas ketidakpercayaan masyarakat terhadap organisasi masjid dan takmir/pengurusnya.

Akuntabilitas publik yaitu kewajiban penerima tanggung jawab untuk mengelola, melaporkan dan mengungkapkan segala aktivitas dan kegiatan yang berkaitan dengan penggunaan sumber daya publik, (Nurjannah, 2018). Suginam (2020) menjelaskan akuntabilitas merupakan prinsip yang menjamin bahwa setiap kegiatan suatu entitas atau perorangan dapat dipertanggungjawabkan secara terbuka kepada masyarakat. Akuntabilitas publik terdiri atas, akuntabilitas vertikal yang merupakan akuntabilitas kepada otoritas yang lebih tinggi, dan akuntabilitas horizontal, merupakan akuntabilitas kepada publik secara luas atau terhadap sesama lembaga lainnya yang tidak memiliki hubungan atasan bawahan (Sochimin, 2016).

Praktik akuntansi sebagai instrumen transparansi dan akuntabilitas di masjid masih kurang mendapatkan perhatian khusus. Padahal, praktik akuntabilitas dan keterbukaan (transparansi) pada masjid diperlukan untuk 
melakukan pembenahan administrasi termasuk publikasi dan pertanggungjawaban laporan keuangan.

Pengurus masjid merupakan satu kesatuan organisasi yang harus bekerja sama dalam menjalankan semua kegiatan yang ada. Dalam hali ini, bendahara masjid memiliki tugas dan peranan yang lebih mengenai pengelolaan keuangan dan harus memberikan laporan keuangan kepada pengurus lain serta pemberi dana. Pada entitas publik, akuntabilitas dan transparansi menjadi penting untuk bertahan dan memaksimalkan perannya karena keduanya merupakan kontrol sebuah organisasi. Menurut Nurjannah (2018), akuntabilitas akan semakin membaik jika didukung oleh suatu sistem akuntansi yang menghasilkan informasi yang tepat waktu, akurat dan dapat dipertanggungjawabkan.

Standar akuntansi untuk penyusunan pelaporan keuangan pada entitas nonlaba telah diatur dan ditetapkan oleh IAI pada tahun 2009 melalui Pernyataan Standar Akuntansi Keuangan (PSAK) No. 45. PSAK 45 mengalami proses revisi tahun 2011 sebelum akhirnya digantikan oleh Interpretasi Standar Akuntansi Keuangan (ISAK) Nomor 35 tentang Pelaporan Keuangan Entitas Nonlaba pada tahun 2018. ISAK 35 mengungkapkan bahwa organisasi nonlaba merupakan suatu instansi yang aktivitias utamanya tidak berorientasi mencari laba namun bukan berarti tidak menghasilkan laba (nirlaba). Menurut ISAK 35, laporan keuangan entitas nonlaba meliputi laporan posisi keuangan, laporan penghasilan komprehensif, laporan arus kas dan catatan atas laporan keuangan. Dengan adanya pengelolaan kas yang baik, kita dapat menyediakan informasi kepada para donatur maupun pada pihak-pihak lain yang berkepentingan.

Penelitian ini bertujuan untuk menjawab bagaimana akuntabilitas dan penerapan pelaporan keuangan yang dillakukan masjid di wilayah Kecamatan Kedungbanteng, apakah sudah akuntabel dan sesuai dengan standar akuntansi entitas nirlaba yang diatur dalam ISAK 35.

\section{METODE}

\section{Jenis Penelitian}

Jenis penelitian ini adalah menggunakan metode deskriptif kualitatif. Menurut Bungin (2008), penelitian deskriptif bertujuan untuk menggambarkan, meringkaskan berbagai kondisi, berbagai situasi, atau berbagai fenomena realitas sosial yang ada di masyarakat yang menjadi objek penelitian, dan berupaya menarik realitas itu ke permukaan sebagai suatu ciri, karakter, sifat, model, tanda, atau gambaran tentang kondisi, situasi maupun fenomena tertentu.

\section{Populasi dan Sampel}

Populasi dalam penelitian ini adalah seluruh masjid yang ada di wilayah kecamatan Kedungbanteng yang berjumlah 53 Masjid Jami (Masjid utama). Populasi ini diambil dari situs resmi Sistem Informasi Masjid Kementrian Agama Republik Indonesia (SIMAS
KEMENAG) tahun 2020. Untuk pengambilan sampel dalam penelitian ini yaitu dengan pemakaian kuota dan teknik Probability sampling dengan Purposive sampling. Jumlah Masjid yang akan dijadikan sampel sebanyak 1 Masjid tiap desa. Peneliti menetapkan mengambil 1 masjid untuk menjadi sampel penelitian dari setiap desa berdasarkan data luas tanah serta bangunan yang terbesar dan memiliki berbagai macam kegiatan lain yang dilaksanakan selain untuk kegiatan solat fardhu, sehingga sampel dalam penelitian ini dapat dikatakan aktif.

Data dalam penelitian ini akan dikumpulkan melalui teknis pengumpulan data dilokasi penelitian dengan cara observasi, wawancara dan dokumentasi.

\section{Teknik Analisis Data \\ Pengumpulan Data}

Tahap ini peneliti mengumpulkan data dengan mencatat hasil wawancara dan observasi yang telah dilakukan di Masjid yang menjadi sampel.

\section{Reduksi Data}

Pada tahapan ini peneliti merangkum, mendeskripsikan dan memilih data atau informasi yang diperoleh dari responden pihak masjid, kemudian memfokuskan berdasarkan masalah yang akan diungkapkan yaitu tentang akuntabilitas dan penerapan laporan keuangan organisasi nirlaba berdasarkan ISAK 35 .

\section{Penyajian Data}

Penyajian data merupakan informasi yang muemungkinkan kesimpulan riset dilakukan. Dalam hal ini penyajian data yang disajikan peneliti menggunakan metode interpretif. Diawali dengan menejelaskan rumusan masalah dengan persepsi informan sebagai pengantar mengenai pertanyaan yang diajukan oleh peneliti. Data yang di peroleh yang bererhubungan dengan rumusan masalah akan dijelaskan terlebih dahulu. Kemudian data-data tersebut dihubungkan dengan teori untuk bisa menjawab rumusan masalah. Karena penelitian ini menggunakan metode interpretif, maka penyajian hanya sebatas pemaparan antara data yang diperoleh dengan teori untuk menjawab permasalahan.

\section{Penarikan Kesimpulan}

Proses ini dilakukan selama penelitian ini berlangsung dan setelah terkumpulnya data-data yang diperlukan. Setelah semua data yang diperlukan sudah memadai, maka dapat dilakukan analisis sehingga dapat ditarik kesimpulan sementara dan setelah semua data lengkap maka dapat ditarik kesimpulan akhir. Penarikan kesimpulan dilakukan secara bertahap, yang pertama menyusun simpulan sementara, tetapi dengan bertambahnya data maka perlu dilakukan verifikasi data, yaitu dengan cara mempelajari kembali data-data yang 
ada. Kedua, menarik simpulan akhir setelah kegiatan selesai. Penarikan kesimpulan dilakukan dengan jalan membandingkan kesesuain pernyataan responden dengan kriteria akuntabilitas yang sudah ditentukan.

\section{HASIL DAN PEMBAHASAN}

Pengumpulan data penelitian yang berupa wawancara dilakukan setelah menetapkan 14 masjid terpilih dan dilakukan kepada 14 informan pada masjid di wilayah kecamatan Kedungbanteng yang telah ditetapkan menjadi sampel penelitian. Wawancara ini dilaksanakan dengan cara mendatangi secara langsung setiap informan dan ada pula yang melalui komunikasi jarak jauh via telepon ataupun aplikasi whatsapp. Informan dalam penelitian ini memiliki karakteristik yang tidak sama. Dijelaskan berdasarkan jabatannya di dalam organisasi masjid, 1 informan merupakan takmir aktif yang mengelola keseluruhan masjid, 1 informan merupakan ketua takmir dan 12 lainnya merupakan bendahara masjid. Kriteria akuntabilitas sektor publik dirujuk dari penelitian milik Aman, Al-Shabail dan Mohammed (2013). Rangkuman hasil wawancara dapat dilhat di tabel dibawah ini:

Tabel 1. Rangkuman Hasil Wawancara

\begin{tabular}{|c|c|c|c|}
\hline Aspek & Kriteria & Indikator & Temuan \\
\hline \multirow[t]{6}{*}{ Akuntabilitas } & Transparansi & $\begin{array}{l}\text { Adanya publikasi dana kas } \\
\text { masjid }\end{array}$ & $\begin{array}{l}\text { Sebagian besar masjid di wilayah kecamatan } \\
\text { kedungbanteng sudah melakukan publikasi dana } \\
\text { kas masjid baik secara langsung maupun tertulis, } \\
\text { meskipun tidak secara berkala. }\end{array}$ \\
\hline & Pertanggung & Adanya pencatatan dana & Sebagian besar masjid di wilayah kecamatan \\
\hline & Jawaban & kas yang dilakukan masjid & $\begin{array}{l}\text { Kedungbanteng telah membuat pencatatan } \\
\text { sederhana terkait dana kas masuk maupun keluar }\end{array}$ \\
\hline & Pengendalian & $\begin{array}{l}\text { Penggunaan dana kas } \\
\text { dengan baik }\end{array}$ & $\begin{array}{l}\text { Sebagian besar masjid di wilayah kecamatan } \\
\text { Kedungbanteng telah melakukan pengendalian } \\
\text { dana kas secara baik dengan pengalokasian dana } \\
\text { masjid secara jelas }\end{array}$ \\
\hline & Tanggung Jawab & $\begin{array}{l}\text { Kesanggupan atas tugas } \\
\text { yang diemban }\end{array}$ & $\begin{array}{l}\text { Sebagian besar pengurus masjid di wilayah } \\
\text { kecamatan Kedungbanteng dipilih tanpa ada } \\
\text { paksaan dan telah melakukan tugasnya dengan } \\
\text { baik }\end{array}$ \\
\hline & Responsivitas & $\begin{array}{l}\text { Daya tanggap masjid } \\
\text { terhadap harapan jama'ah } \\
\text { dan masyarakat }\end{array}$ & $\begin{array}{l}\text { Sebagian besar pengurus masjid berupaya } \\
\text { memenuhi saran dan kritik yang telah diberikan } \\
\text { oleh jama'ah dan masyarakat }\end{array}$ \\
\hline ISAK 35 & $\begin{array}{l}\text { Ada } 5 \text { bentuk laporan } \\
\text { keuangan yang } \\
\text { dibentuk }\end{array}$ & $\begin{array}{l}\text { Adanya Kesesuain bentuk } \\
\text { catatan laporan keuangan } \\
\text { dengan standar ISAK } 35\end{array}$ & $\begin{array}{l}\text { Sebagian besar masjid di wilayah kecamatan } \\
\text { Kedungbanteng belum menerapkan ISAK } 35 \text { dan } \\
\text { masih berupa pencatatan yang sederhana }\end{array}$ \\
\hline
\end{tabular}

Berdasarkan hasil temuan yang peneliti dapatkan dari hasil wawancara dengan informan, dapat diketahui bahwa sebagian besar masjid di wilayah kecamatan Kedungbanteng sudah akuntabel tetapi dalam pencatatan laporan keuangan yang dibuat belum sesuai dengan standar ISAK 35.

\section{Akuntabilitas Masjid di Wilayah Kecamatan Kedungbanteng Transparansi}

Berdasarkan kutipan wawancara yang telah peneliti lakukan dengan beberapa takmir masjid di wilayah kecamatan Kedungbanteng, diketahui bahwa masjid di kecamatan Kedungbanteng rata-rata telah bersifat transparansi dalam pelaporan keuangannya dan diperoleh data bahwa masjid di wilayah kecamatan Kedungbanteng telah menerapkan transparansi laporan keuangan ke sesama anggota takmir (pengurus) Masjid yang dilakukan berkala tetapi tidak terjadwal. Bentuk transparansi kepada masyarakat selaku pemberi dana yang dilakukan yaitu secara lisan pada saat menjelang solat Jum'at dan secara tertulis di papan pengumuman yang tersedia.

\section{Pertanggungjawaban}

Takmir masjid yang menjadi sampel dalam penelitian ini telah melakukan bentuk pertanggungjawaban dibuktikan dengan adanya pencatatan disertai arisp berupa nota yang dilakukan oleh bendahara masjid. Untuk alur pencatatan pengeluaran dan pemasukan rata-rata di masjid yang berada di wilayah kecamatan Kedungbanteng adalah sebagai berikut:

a. Dana dari kotak amal dihimpun secara periodik (biasanya satu minggu sekali pada hari Jum'at), kemudian dicatat jumlahnya.

b. Donatur menyerahkan uangnya kepada pengurus masjid, jika bukan bendahara yang menerima, maka pengurus yang menerima menyerahkan kepada bendahara masjid terlebih dahulu, lalu bendahara mencatat nama dan jumlahnya.

c. Setiap kas yang digunakan, menyerahkan bon pembelian kepada bendahara kemudian dicatat. 
d. Pada akhir bulan, kas yang masuk baik dari kotak amal maupun sumbangan donatur dijumlahkan kemudian dikurangi dengan pengeluaran.

e. Bentuk pencatatan yang dilakukan, bersifat sederhana (Debet, Kredit, Saldo).

\section{Pengendalian}

Dalam hal entitas publik khususnya di sini yaitu organisasi masjid, dapat dikatakan bahwa ratarata masjid di kecamatan Kedungbanteng telah melakukan pengendalian kas masjid secara baik dengan pengalokasian dana masjid yang diperoleh dari masyarakat ataupun Jama'ah secara jelas. Dapat dikategorikan sebagai pengeluaran rutin dan pengeluaran tidak rutin. Pengeluaran rutin merupakan pengeluaran yang dikeluarkan untuk operasional yang selalu ada setiap bulan, seperti pembayaran honor petugas masjid (sebagai petugas kebersihan, membayar gaji satpam yang berjaga pada saat solat Jum'at), uang transport khotib, pembayaran listrik, air.

Sedangkan pengeluaran tidak rutin merupakan pengeluaran yang dikeluarkan tidak selalu ada tiap bulannya. Dana yang digunakan diambil secara spontan dari kas yang ada karena ada kegiatan masjid, seperti untuk perayaan hari besar Islam yang diadakan setiap tahun.

\section{Tanggungjawab}

Berdasarkan hasil wawancara, dapat disimpulkan bahwa takmir (khususnya bendahara) masjid yang berada di wilayah kecamatan Kedungbanteng telah melaksanakan tanggung jawabnya dengan baik dibuktikan dengan:

a. Takmir (bendahara) dipilih langsung oleh Jama'ah ataupun secara sukarela mengajukan diri.

b. Takmir (bendahara) telah melakukan tugasnya yaitu mengumpulkan dan melakukan pencatatan kas masuk ataupun keluar.

c. Anggota takmir telah melakukan manajemen pengelolaan masjid secara baik dibuktikan dengan ketersediaan fasilitas penunjang ibadah lainnya seperti ketersediaan toilet, tempat wudhu, mukena dan lainnya.

\section{Responsivitas}

Dari hasil wawancara yang telah peneliti lakukan dengan beberapa informan, dapat dikatakan bahwa masjid di wilayah kecamatan Kedungbanteng terbukti responsiv dengan saran dan kritik yang diberikan oleh jama'ah dan masyarakat dibuktikan dengan anggota takmir mendengar dengan baik saran dan kritik yang diberikan oleh jama'ah dan berupaya memenuhi keinginan jama'ah atau masyarakat tersebut.

\section{SIMPULAN}

Berdasarkan hasil dan pembahasan analisa dapat ditarik kesimpulan sebagai berikut:

1. Masjid di wilayah kecamatan Kedungbanteng sudah akuntabel dalam pengelolaan keuangannya

Ditetapkannya kesimpulan akhir ini dilakukan peneliti setelah membandingkan kembali kriteria akuntabilitas yang sudah ditetapkan dengan hasil wawancara yang diperoleh mengenai perolehan sumber dana masjid yang dikelola dengan baik (dibuktikan adanya ketersediaan fasilitas yang memadai guna menunjang kegiatan ibadah) serta pelaksanaan informasi keadaan keuangan masjid yang dilakukan rutin oleh takmir kepada masyarakat selaku pemberi sumber dana. Namun, pempublikasian rutin yang dilaksanakan ke sesama anggota takmir (pengurus) masjid masih jarang dilakukan karena sudah dianggap cukup pada laporan yang disampaikan sebelum pelaksanaan solat Jum'at. Pengalokasian dana guna melakukan pemeliharaan masjid, untuk pendanaan yang bersifat rutin maupun tidak rutin pun tidak lepas dari ketersediaan takmir masjid yang secara sukarela mereka lakukan tanpa menerima ataupun mengharapkan timbal balik atas apa yang mereka telah laksanakan.

2. Masjid di wilayah kecamatan Kedungbanteng belum menerapkan ISAK 35 dalam pembuatan laporan keuangan

Penerapan Interpretasi Standar Akuntasi Keuangan (ISAK) No 35 mengenai penyajian laporan keuangan entitas berorientasi nonlaba (dalam hal ini masjid) belum diterapkan masjid di wilayah kecamatan Kedungbanteng. Dikarenakan bendahara masjid juga mengaku istilah tersebut asing bagi mereka dan yang terpenting adalah sistemnya masyarakat saling percaya kepada pengelola selaku yang bertugas. Walaupun belum adanya penerapan standar laporan keuangan yang telah dibentuk oleh Ikatan Akuntan Indonesia (IAI), namun secara umum tujuan penyusunan laporan keuangan masjid yang berada di wilayah kecamatan Kedungbanteng ini telah tercapai meskipun masih ada informasi-informasi tertentu belum jelas. Selain itu, pengelolaan keuangan masjid juga telah menyajikan laporan keuangannya baik dengan sistem manual maupun bantuan Microsoft Excel sehingga laporan keuangan yang dihasilkan sudah rinci.

\section{DAFTAR PUSTAKA}

Andarsari, P. R. (2016). Laporan Keuangan Organisasi nirlaba (lembaga masjid). EKONIKA Jurnal Ekonomi Universitas Kadiri, 1(2).

Aman, A., Al-Shbail, T. A., \& Mohammed, Z. (2013). Enhancing public organizations accountability through E-Government systems. International Journal of Conceptions on Management and Social Sciences, 1(1), 15-21. 
Bungin, B. (2008). Analisis data penelitian kualitatif. Jakarta: Raja Grafindo Persada

Indonesia, I. A. (2018). Interpretasi Standar Akuntansi Keuangan (ISAK) No. 35 tentang penyajian Laporan Keuangan Entitas Berorientasi Nonlaba. Jakarta: IFAC.

Indonesia, I. A. (2009). Pernyataan Standar Akuntansi Keuangan (PSAK) No. 45 Tentang Standar Akuntansi Untuk Entitas Nirlaba. Jakarta: IFAC.

Indonesia, I. A. (2011). Pernyataan Standar Akuntansi Keuangan (PSAK) No. 45 Tentang Standar Akuntansi Untuk Entitas Nirlaba. Jakarta: IFAC.

Nurjannah, N. (2018). Akuntabilitas dan Pengelolaan Keuangan Masjid: PSAK No. 45 tentang Pelaporan Keuangan Organisasi Nirlaba (Doctoral dissertation, Universitas Islam Negeri Alauddin Makassar).

Pontoh, W. (2013). Akuntansi konsep dan praktik. Penerbitan Halaman Moeka. Jakarta Barat.

Sochimin, S. (2016). Manajemen Keuangan Masjid Berbasis Pemberdayaan Ekonomi Umat. el-Jizya: Jurnal Ekonomi Islam, 4(1), 119-150.

Suginam, S. (2020). Akuntabilitas Pengelolaan Dana Zakat Berbasis Teknologi Informasi Pada Organisasi Pengelola Zakat (OPZ). ARBITRASE: Journal of Economics and Accounting, 1(1), 8689.

www.simas.kemenag.go.id 